\title{
Growth and Yield of Banana as Influenced by Age of Secondary Hardened Tissue Culture Plantlets
}

\author{
L. Dhanabati ${ }^{1}$ * and S.K. Sarkar ${ }^{2}$ \\ ${ }^{1}$ College of Post-Graduate Studies, Central Agricultural University (Imphal), \\ Umiam-793103, Meghalaya, India \\ ${ }^{2}$ Department of Fruits and Orchard Management, Faculty of Horticulture, Bidhan Chandra \\ Krishi Viswavidyalaya, Mohanpur, Nadia-741252, West Bengal, India \\ *Corresponding author
}

\section{A B S T R A C T}

Keywords

Banana

Secondary

Hardened, Tissue

Culture Plantlets

Article Info

Accepted:

10 March 2019

Available Online:

10 April 2019
An experiment was conducted at Banana Research Centre, Mondouri under Bidhan Chandra Krishi Viswavidyalaya, Mohanpur, Nadia, West Bengal with five treatments and four replication at randomized block design. Two consecutive plant crop of cv. Grand Naine was planted during September of 2010 and 2011. Observations were recorded on various plant growth characters, yield and yield contributing characters. The 2 months secondary hardened plantlets (T2) and 3 months secondary hardened plantlets (T3) were found to be the best optimum age of tissue culture plantlets for better growth and yield of banana.

\section{Introduction}

Banana (Musa sp.) is one of the most important fruit crops in India. It grows all over the country in large and small scale. It is affordable by all classes of people and available throughout the year. In recent times, it has been observed, in vitro propagated banana performs better than the sucker derived plants. Moreover low rate of multiplication limits the method of propagation through suckers. Uniformity in flowering, higher yield and early harvest of tissue culture propagated plants has been demonstrated at different locations. The adoption of tissue culture propagated plants among growers has been slow mainly because of high costs. However adoption of drip irrigation and better management system resulted in enhance return from tissue cultured plants. Recently several complains were being received from banana growers regarding uneven growth, low yield and medium quality fruits of tissue cultured planting material which might be due to age of plantlets as disclosed by few studies carried till date. The hardening is a process of transferring in-vitro plants to the soil after acclimatization. During hardening the plantlets undergo physiological adaptation to 
the changed external factors like temperature, relative humidity, water and nutrient supply. Variation in yield and quality of tissue culture banana might be due to age of plantlets. The knowledge of optimum plantlet size could save the production cost for tissue culture laboratories and for growers the overaged or underaged plantlets performance knowledge is highly essential for getting maximum return. Therefore field experiment was conducted at Banana Research Centre, Bidhan Chandra Krishi Viswavidyalaya, Mondouri during the years 2010-2013 to study on the growth and yield of banana cv. Grand naine as influenced by variably hardened tissue cultured plantlets.

\section{Materials and Methods}

The experiment was carried out at the Banana Research Centre, Mondouri under Bidhan Chandra Krishi Viswavidyalaya, Mohanpur, Nadia, West Bengal during 2010 to 2013. The centre is situated at $89{ }^{\circ} \mathrm{E}$ Longitude and 23.5 ${ }^{\circ} \mathrm{N}$ latitude with an altitude of $9.75 \mathrm{~m}$ above mean sea level. The climate of the Research Station is Sub-tropical humid with the maximum temperature varying from $22.3^{\circ} \mathrm{C}$ to $38.8^{\circ} \mathrm{C}$ and that of minimum from $10.5^{\circ} \mathrm{C}$ to $23.1^{\circ} \mathrm{C}$ during the period of investigation. The experiment was laid out with five treatments; each replicated four times having 16 number of plants per treatment with a spacing of $2 \mathrm{~m} \times 2 \mathrm{~m}$ in a randomized block design. The first planting was carried out on 04.09.2010 and the second planting on 04.09.2011. The treatments were 1 month, 2 months, 3 months, 4 months and 5 months secondary hardened tissue culture plantlets. In-vitro materials were taken out from the laboratory at monthly intervals on $4^{\text {th }}$ of each month during April, May, June, July and August of both the year. Each lot after one month primary hardening were kept in net house for secondary hardening. All the plantlets were taken out from net house collectively before planting.

\section{Results and Discussion}

The plant height at different stages of observation in variably hardened tissue culture plant varied significantly. The 5 months secondary hardened plantlets $\left(\mathrm{T}_{5}\right)$ recorded maximum height at all stages of growth except 5 months after planting (MAP) in which plant height was maximum in 2 month secondary hardened plantlets $\left(\mathrm{T}_{2}\right)$ which is closely followed by 5 month hardened plantlets $\left(\mathrm{T}_{5}\right)$. Further 1 month hardened treatment $\left(T_{1}\right)$ recorded minimum plant height at planting, 3 months after planting (MAP) and at shooting. During 5 MAP and 7 MAP minimum height was observed in 3 month hardened plants $\left(T_{3}\right)$. After taking out from hardening green house the plantlets showed progressing increase in plant height in field depending upon increasing duration of hardening. At planting, 3 MAP, 5 MAP, 7 MAP and shooting the 5 month hardened plants had $43.1 \%, 35.2 \%$, $2.1 \%, 3.9 \%$ and $5.3 \%$ more plant height respectively than 1 month hardened treatment, depicting that major height difference persisted upto 3 MAP only (Table 1).

The plant girth was maximum in 5 month hardened plant $\left(\mathrm{T}_{5}\right)$ at planting, $3 \mathrm{MAP}$ and 5 MAP. In 7 MAP and at shooting plant girth was maximum in 2 month hardened plants $\left(T_{2}\right)$. Throughout the growth stages plant girth was minimum in 1 month hardened plants $\left(\mathrm{T}_{1}\right)$. Plant girth was $89.9 \%, 23.7 \%$ and $14.7 \%$ more in 5 month hardened plant $\left(\mathrm{T}_{5}\right)$ at planting, 3 MAP and 5 MAP respectively compared to 1 month hardened plants $\left(\mathrm{T}_{1}\right)$. After 5 MAP, the 3 month hardened plants $\left(\mathrm{T}_{3}\right)$ superseded the 5 month hardened plants $\left(\mathrm{T}_{5}\right)$ with regard to plant girth (Table 1$)$.

It is a known fact that the initial growth of tissue culture raised plants is quite slow because of hormonal effect in tissue culture medium. Extending the secondary hardening 
of plantlets upto 5 months, plantlets overcome the growth suppression effect during early growth while in hardening chamber, which may have resulted higher plant height and plant girth in 5 month hardened plantlet $\left(\mathrm{T}_{5}\right)$ compared to other treatments, which persisted upto 3 MAP or 5 MAP. However shorter duration secondary hardened plants once established in field i.e., after 5 MAP had exceeded the height and girth of 5 month hardened plants $\left(\mathrm{T}_{5}\right)$.

The number of functional leaves was minimum in 2 month hardened plantlets at planting. Thereafter the same treatment had maximum number of functional leaves at all stages of growth. 3 months hardened plants $\left(\mathrm{T}_{3}\right)$ at 3MAP and 4 months hardened plants $\left(\mathrm{T}_{4}\right)$ at 5 MAP had lowest number of functional leaves. However at later stages i.e., 7 MAP and shooting 5 months hardened plantlets $\left(\mathrm{T}_{5}\right)$ had minimum number of functional leaves.

The phyllochron value at monthly interval revealed maximum value (days) in 5 months hardened plants $\left(\mathrm{T}_{5}\right)$ in all months of observation. This envisages lower production of leaves at any specific period, which finally recorded least number of functional leaves at 7 MAP and at shooting in 5 months hardened plants $\left(\mathrm{T}_{5}\right)$. Higher values of phyllochron in 4 month hardened plants $\left(\mathrm{T}_{4}\right)$ during November, December and January which coincided with 5 MAP also resultes less number of functional leaves for this treatment. Phyllochron values from November onward was least in 2 month hardened plants $\left(\mathrm{T}_{2}\right)$ also resulted maximum number of functional leaves in this treatment at 3 MAP onward. Comparatively higher plant height at 5 MAP onward and highest plant girth at 7 MAP and at shooting stage in 2 month hardened plants $\left(\mathrm{T}_{2}\right)$ may be due to better establishment in field, ultimately resulting in lower phyllochron and more number of functional leaves at later stages of growth. The result of phyllochron shows that the 2 month secondary hardened plants recorded the lowest phyllochron (Table 2). Therefore, the present investigation was in conformity with the work of Pillai and Shanmugavelu (1979) who observed decrease in phyllochron due to increase in the number of functional leaves. However, irrespective of the treatments the phyllochron so observed in the present instance do confirm the work of Stover (1984).

\section{Leaf area and leaf area index}

The leaf area at different growth stages of observation in variably hardened tissue culture plants varied significantly. The 5 months secondary hardened plants $\left(\mathrm{T}_{5}\right)$ showed the maximum leaf area at planting $\left(0.03 \mathrm{~m}^{2}\right)$, at $3 \mathrm{MAP}\left(0.16 \mathrm{~m}^{2}\right)$ and at shooting $\left(0.02 \mathrm{~m}^{2}\right)$.

However, at 7 MAP and at shooting the leaf area was higher in one month secondary hardened plants $\left(0.69 \mathrm{~m}^{2}\right)$ and 3 months secondary hardened plants $\left(1.16 \mathrm{~m}^{2}\right)$ compared with 5 months secondary hardened plants $\left(T_{5}\right)$ recording $0.62 \mathrm{~m}^{2}$ and $0.98 \mathrm{~m}^{2}$ at $7 \mathrm{MAP}$ and at shooting respectively (Table 3 ). The plantlets showed progressive increase in the leaf area with increasing growth under the field condition. However, tissue cultured plantlets need an acclimatization period for their establishment in the field condition and in overcoming the hormonal effect of the culture medium, which may be the probable reasons for the slow increase in the leaf area during the initial growth period i.e., up to 5 MAP in field. Extending the secondary hardening of plantlets up to 5 months overcome the growth suppression effect of in vitro hormones and getting acclimatization period during hardening thereby promoting the growth and resulted in higher leaf area compared to other treatments. 
Table.1 Effect of variably hardened tissue cultured plantlets on plant height $(\mathrm{cm})$ at shooting stage of banana cv. Grand Naine (AAA) in two consecutive plant crop

\begin{tabular}{|c|c|c|c|c|c|c|c|c|c|}
\hline \multirow[t]{2}{*}{ Treatment } & \multicolumn{3}{|c|}{ Plant height } & \multicolumn{3}{|c|}{ Plant girth } & \multicolumn{3}{|c|}{ No.of leaves } \\
\hline & $\begin{array}{l}2010- \\
2011\end{array}$ & $\begin{array}{l}2011- \\
2012\end{array}$ & Pooled & $\begin{array}{l}2010- \\
2011\end{array}$ & $\begin{array}{l}\text { 2011- } \\
2012\end{array}$ & Pooled & $\begin{array}{l}2010- \\
2011\end{array}$ & $\begin{array}{l}\text { 2011- } \\
2012\end{array}$ & Pooled \\
\hline $\mathbf{T}_{1}$ & 214.92 & 218.97 & 216.95 & 70.58 & 73.33 & 71.95 & 14.10 & 14.61 & 14.36 \\
\hline $\mathbf{T}_{2}$ & 225.06 & 225.81 & 225.43 & 75.87 & 80.38 & 78.12 & 14.71 & 15.56 & 15.13 \\
\hline $\mathbf{T}_{3}$ & 222.81 & 218.18 & 220.49 & 75.37 & 75.15 & 75.26 & 14.92 & 15.13 & 15.03 \\
\hline $\mathbf{T}_{4}$ & 220.75 & 226.25 & 223.50 & 73.69 & 73.44 & 73.57 & 14.12 & 14.32 & 14.22 \\
\hline $\mathbf{T}_{5}$ & 224.93 & 232.03 & 228.48 & 72.59 & 77.67 & 75.13 & 13.10 & 13.18 & 13.14 \\
\hline SE.m \pm & 0.63 & 1.01 & 0.60 & 0.35 & 0.48 & 0.38 & 0.07 & 0.08 & 0.06 \\
\hline CD $(5 \%)$ & 1.96 & 3.11 & 1.86 & 1.08 & 1.48 & 1.17 & 0.22 & 0.23 & 0.20 \\
\hline
\end{tabular}

Table.2 Effect of variably hardened tissue cultured plantlets on phyllochron (days) of banana cv. Grand Naine (AAA) in two consecutive plant crop

\begin{tabular}{|c|c|c|c|c|c|c|c|c|c|c|c|c|}
\hline & \multicolumn{3}{|c|}{ Sep } & \multicolumn{3}{|c|}{ Oct } & \multicolumn{3}{|c|}{ Nov } & \multicolumn{3}{|c|}{ Dec } \\
\hline Treatment & $\begin{array}{r}2010- \\
2011\end{array}$ & $\begin{array}{r}2011- \\
2012\end{array}$ & Pooled & $\begin{array}{r}2010- \\
2011\end{array}$ & $\begin{array}{r}2011- \\
2012\end{array}$ & Pooled & $\begin{array}{r}2010- \\
2011\end{array}$ & $\begin{array}{r}2011- \\
2012\end{array}$ & Pooled & $2010-2011$ & 2011-2012 & Pooled \\
\hline $\mathbf{T}_{1}$ & 7.08 & 7.04 & 7.06 & 6.82 & 6.68 & 6.75 & 7.20 & 7.13 & 7.17 & 8.93 & 8.91 & 8.92 \\
\hline $\mathbf{T}_{2}$ & 6.91 & 6.70 & 6.81 & 6.77 & 6.43 & 6.60 & 7.12 & 6.75 & 6.94 & 8.61 & 8.50 & 8.56 \\
\hline $\mathbf{T}_{\mathbf{3}}$ & 6.73 & 6.66 & 6.69 & 6.74 & 6.40 & 6.57 & 7.06 & 6.88 & 6.97 & 8.83 & 8.63 & 8.73 \\
\hline $\mathbf{T}_{4}$ & 7.21 & 7.16 & 7.18 & 6.94 & 6.53 & 6.73 & 7.37 & 7.34 & 7.36 & 9.14 & 9.09 & 9.12 \\
\hline $\mathbf{T}_{5}$ & 7.46 & 7.42 & 7.44 & 7.25 & 6.98 & 7.11 & 7.61 & 7.59 & 7.60 & 9.41 & 9.34 & 9.37 \\
\hline SE.m \pm & 0.03 & 0.04 & 0.03 & 0.05 & 0.05 & 0.05 & 0.055 & 0.04 & 0.04 & 0.05 & 0.04 & 0.04 \\
\hline CD (5\%) & 0.11 & 0.13 & 0.10 & 0.17 & 0.17 & 0.15 & 0.170 & 0.13 & 0.13 & 0.15 & 0.14 & 0.12 \\
\hline
\end{tabular}


Contd:......

\begin{tabular}{|c|c|c|c|c|c|c|c|c|c|c|c|c|c|c|}
\hline \multicolumn{3}{|c|}{ Jan } & \multicolumn{3}{|c|}{ Feb } & \multicolumn{3}{|c|}{ March } & \multicolumn{3}{|c|}{ April } & \multicolumn{3}{|c|}{ May } \\
\hline $\begin{array}{r}2010- \\
2011\end{array}$ & $\begin{array}{r}2011- \\
2012\end{array}$ & Pooled & $\begin{array}{r}2010- \\
2011\end{array}$ & $\begin{array}{r}2011- \\
2012\end{array}$ & Pooled & $\begin{array}{r}2010- \\
2011\end{array}$ & $\begin{array}{r}2011- \\
2012\end{array}$ & Pooled & $\begin{array}{r}2010- \\
2011\end{array}$ & $\begin{array}{r}2011- \\
2012\end{array}$ & Pooled & $\begin{array}{r}2010- \\
2011\end{array}$ & $\begin{array}{r}2011- \\
2012\end{array}$ & Pooled \\
\hline 9.24 & 9.18 & 9.21 & 8.58 & 8.42 & 8.50 & 8.27 & 8.14 & 8.21 & 8.05 & 7.95 & 8.00 & 8.26 & 8.13 & 8.19 \\
\hline 8.86 & 8.80 & 8.83 & 8.15 & 7.99 & 8.07 & 7.69 & 7.53 & 7.61 & 7.41 & 7.36 & 7.39 & 7.87 & 7.56 & 7.72 \\
\hline 9.04 & 8.93 & 8.98 & 8.30 & 8.11 & 8.20 & 8.31 & 7.95 & 8.13 & 7.86 & 7.81 & 7.83 & 8.17 & 8.06 & 8.11 \\
\hline 9.56 & 9.39 & 9.47 & 8.90 & 8.52 & 8.71 & 8.48 & 8.23 & 8.35 & 8.08 & 8.08 & 8.08 & 8.74 & 8.37 & 8.55 \\
\hline 9.79 & 9.49 & 9.64 & 9.15 & 9.04 & 9.09 & 8.68 & 8.46 & 8.57 & 8.33 & 8.14 & 8.23 & 8.90 & 8.56 & 8.73 \\
\hline 0.04 & 0.03 & 0.02 & 0.06 & 0.08 & 0.07 & 0.08 & 0.13 & 0.09 & 0.06 & 0.10 & 0.07 & 0.06 & 0.05 & 0.05 \\
\hline 0.11 & 0.10 & 0.07 & 0.17 & 0.26 & 0.20 & 0.25 & 0.39 & 0.27 & 0.19 & 0.30 & 0.22 & 0.18 & 0.16 & 0.16 \\
\hline
\end{tabular}

Table.3 Effect of variably hardened tissue cultured plantlets on leaf area (m2) and LAI at different growth stages of banana cv. Grand Naine (AAA) in two consecutive plant crop

\begin{tabular}{|c|c|c|c|c|c|c|c|c|c|c|c|c|c|c|c|c|c|c|}
\hline \multirow{3}{*}{ Treatment } & \multicolumn{15}{|c|}{ Leaf Area $\left(\mathrm{m}^{2}\right)$} & \multicolumn{3}{|c|}{$\begin{array}{l}\text { Leaf Area Index(LAI) at } \\
\text { Shooting }\end{array}$} \\
\hline & \multicolumn{3}{|c|}{ At planting } & \multicolumn{3}{|c|}{3 MAP } & \multicolumn{3}{|c|}{5 MAP } & \multicolumn{3}{|c|}{7 MAP } & \multicolumn{3}{|c|}{ At shooting } & & & \\
\hline & $\begin{array}{l}2010- \\
2011\end{array}$ & $\begin{array}{l}2011- \\
2012\end{array}$ & Pooled & $\begin{array}{l}2010- \\
2011\end{array}$ & $\begin{array}{l}2011- \\
2012\end{array}$ & Pooled & $\begin{array}{l}2010- \\
2011\end{array}$ & $\begin{array}{l}\text { 2011- } \\
2012\end{array}$ & Pooled & $\begin{array}{l}2010- \\
2011\end{array}$ & $\begin{array}{l}2011- \\
2012\end{array}$ & Pooled & $\begin{array}{l}2010- \\
2011\end{array}$ & $\begin{array}{l}2011- \\
2012\end{array}$ & Pooled & $\begin{array}{l}2010- \\
2011\end{array}$ & $\begin{array}{l}2011- \\
2012\end{array}$ & Pooled \\
\hline $\mathrm{T}_{1}$ & 0.01 & 0.01 & 0.01 & 0.13 & 0.14 & 0.13 & 0.21 & 0.21 & 0.21 & 0.65 & 0.72 & 0.69 & 1.08 & 1.08 & 1.08 & 0.63 & 0.64 & 0.64 \\
\hline $\mathbf{T}_{2}$ & 0.01 & 0.01 & 0.01 & 0.15 & 0.16 & 0.15 & 0.25 & 0.25 & 0.25 & 0.66 & 0.67 & 0.66 & 1.13 & 1.12 & 1.12 & 0.62 & 0.62 & 0.62 \\
\hline $\mathbf{T}_{3}$ & 0.02 & 0.02 & 0.02 & 0.15 & 0.13 & 0.14 & 0.25 & 0.24 & 0.24 & 0.67 & 0.67 & 0.67 & 1.15 & 1.17 & 1.16 & 0.70 & 0.71 & 0.70 \\
\hline $\mathbf{T}_{4}$ & 0.02 & 0.02 & 0.02 & 0.14 & 0.13 & 0.13 & 0.23 & 0.22 & 0.23 & 0.65 & 0.65 & 0.65 & 1.08 & 1.07 & 1.07 & 0.64 & 0.65 & 0.65 \\
\hline $\mathbf{T}_{5}$ & 0.04 & 0.03 & 0.03 & 0.17 & 0.16 & 0.16 & 0.25 & 0.26 & 0.25 & 0.63 & 0.61 & 0.62 & 0.98 & 0.99 & 0.98 & 0.58 & 0.61 & 0.59 \\
\hline SE.m \pm & 0.001 & 0.001 & 0.001 & 0.004 & 0.006 & 0.003 & 0.006 & 0.009 & 0.008 & 0.005 & 0.008 & 0.006 & 0.006 & 0.008 & 0.005 & 0.003 & 0.005 & 0.003 \\
\hline CD $(5 \%)$ & 0.004 & 0.005 & 0.004 & 0.011 & 0.019 & 0.010 & 0.020 & 0.028 & 0.023 & 0.017 & 0.025 & 0.018 & 0.018 & 0.024 & 0.016 & 0.011 & 0.014 & 0.008 \\
\hline
\end{tabular}


Table.4 Effect of variably hardened tissue cultured plantlets on days to shooting and days to harvest of banana cv.Grand Naine (AAA) in two consecutive plant crop

\begin{tabular}{|c|c|c|c|c|c|c|}
\hline \multicolumn{9}{|c|}{ Days to shooting } & & \multicolumn{3}{c|}{ Days to harvest } \\
\hline Treatment & $\mathbf{2 0 1 0 - 2 0 1 1}$ & $\mathbf{2 0 1 1 - 2 0 1 2}$ & Pooled & $\mathbf{2 0 1 0 - 2 0 1 1}$ & $\mathbf{2 0 1 1 - 2 0 1 2}$ & Pooled \\
\hline $\mathbf{T}_{\mathbf{1}}$ & 276.28 & 265.17 & 270.72 & 365.65 & 355.03 & 360.34 \\
\hline $\mathbf{T}_{\mathbf{2}}$ & 268.64 & 262.84 & 265.74 & 353.13 & 351.84 & 352.48 \\
\hline $\mathbf{T}_{\mathbf{3}}$ & 274.24 & 268.04 & 271.14 & 362.85 & 359.49 & 361.17 \\
\hline $\mathbf{T}_{\mathbf{4}}$ & 281.75 & 273.04 & 277.39 & 371.00 & 360.79 & 365.89 \\
\hline $\mathbf{T}_{\mathbf{5}}$ & 283.41 & 276.40 & 279.91 & 373.21 & 364.15 & 368.68 \\
\hline SE.m \pm & $\mathbf{1 . 6 6}$ & $\mathbf{0 . 6 8}$ & $\mathbf{0 . 9 0}$ & $\mathbf{0 . 7 3}$ & $\mathbf{1 . 6 2}$ & $\mathbf{0 . 9 8}$ \\
\hline CD (5\%) & $\mathbf{5 . 1 2}$ & $\mathbf{2 . 0 9}$ & $\mathbf{2 . 7 6}$ & $\mathbf{2 . 2 4}$ & $\mathbf{4 . 9 8}$ & $\mathbf{3 . 0 1}$ \\
\hline
\end{tabular}

Table.5 Effect of variably hardened tissue cultured plantlets on bunch weight and yield of banana cv. Grand Naine (AAA) in two consecutive plant crop

\begin{tabular}{|c|r|r|r|r|r|r|}
\hline \multicolumn{4}{|c}{ Bunch weight(kg) } & \multicolumn{3}{c|}{ Yield(t/ha) } \\
\hline Treatment & $\mathbf{2 0 1 0 - 2 0 1 1}$ & $\mathbf{2 0 1 1 - 2 0 1 2}$ & Pooled & $\mathbf{2 0 1 0 - 2 0 1 1}$ & $\mathbf{2 0 1 1 - 2 0 1 2}$ & Pooled \\
\hline $\mathbf{T}_{\mathbf{1}}$ & 21.59 & 34.00 & 27.80 & 53.98 & 85.00 & 69.49 \\
\hline $\mathbf{T}_{\mathbf{2}}$ & 23.83 & 35.75 & 29.79 & 59.58 & 89.38 & 74.48 \\
\hline $\mathbf{T}_{\mathbf{3}}$ & 20.54 & 37.50 & 29.02 & 51.35 & 93.75 & 72.55 \\
\hline $\mathbf{T}_{\mathbf{4}}$ & 15.84 & 34.25 & 25.04 & 39.59 & 85.63 & 62.61 \\
\hline $\mathbf{T}_{\mathbf{5}}$ & 14.78 & 33.0 & 23.89 & 36.94 & 82.50 & 59.72 \\
\hline SE.m \pm & $\mathbf{0 . 7 2}$ & $\mathbf{0 . 9 2}$ & $\mathbf{0 . 6 7}$ & $\mathbf{1 . 8 1}$ & $\mathbf{2 . 2 9}$ & $\mathbf{1 . 6 6}$ \\
\hline CD (5\%) & $\mathbf{2 . 2 2}$ & $\mathbf{2 . 8 2}$ & $\mathbf{2 . 0 5}$ & $\mathbf{5 . 5 6}$ & $\mathbf{7 . 0 6}$ & $\mathbf{5 . 1 3}$ \\
\hline
\end{tabular}


Thus, the established secondary plantlets at 3 months of hardening overcome all the growth suppression effect and showed maximum leaf area $\left(1.16 \mathrm{~m}^{2}\right)$ and maximum leaf area index (0.70) at shooting (Table 3). It is quite plausible that the LAI at shooting might very well serve as an index for increasing the yield of bunch. Various evidences amply illustrate that the increase in LAI at shooting would definitely produce a better yield (Stover, 1984).

\section{Days to shooting and harvesting}

Days required for shooting was minimum in both the year of planting as well as in pooled data in 2 month hardened plant $\left(\mathrm{T}_{2}\right)$ while the maximum days required for shooting was observed in 5 month hardened plants $\left(\mathrm{T}_{5}\right)$. Comparatively higher plant height, plant girth, number of functional leaves and lower phyllochron in later stages of growth, triggered efficient assimilation of energy which might have resulted in early differentiation of flower bud in the corm and faster movement through the pseudostem ultimately resulted in early shooting and early harvest in $\mathrm{T}_{2}$ (Table 4). These findings are in conformity with the results obtained by Ingle (2000) and Birhade et al., (1997) though for 3 months old tissue culture plantlets.

The days required for harvesting was maximum in 5 months hardened plantlets $\left(\mathrm{T}_{5}\right)$ while minimum was recorded in 2 months hardened plantlets $\left(\mathrm{T}_{2}\right)$ followed by 1 month hardened plantlets $\left(\mathrm{T}_{1}\right)$. The early vegetative growth, low phyllochron, early shooting might have resulted in early harvest in 2 month hardened plantlets $\left(\mathrm{T}_{2}\right)$.

\section{Yield}

The pooled data revealed that the maximum bunch weight was recorded in 2 month secondary hardened plant $\left(\mathrm{T}_{2}\right)$ followed by 3 month secondary hardened plant $\left(\mathrm{T}_{3}\right)$ while the minimum pooled bunch weight was observed in 5 month secondary hardened plant $\mathrm{T}_{5}$ (Table 5). The results are in conformity with the findings of Jhambhale and Patil (2001) and Digrase et al., (2007). Maximum pseudostem girth, maximum number of functional leaves might have resulted in maximum bunch weight in 2 month secondary hardened plantlets $\left(\mathrm{T}_{2}\right)$ followed by 3 month secondary hardened plant $\left(\mathrm{T}_{3}\right)$ as bunch yield was strongly correlated with pseudostem girth in banana (Teaotia et al.,19970). The higher bunch weight in $\mathrm{T}_{2}$ might be due to more number of functional leaves produced at 3 MAP onwards during all growth stages. This observation was in conformity to the findings of Azhakiamanavalan and Rao (1980). Stover (1984) suggested higher LAI at shooting will result in higher yield accordingly LAI at shooting in $\mathrm{T}_{3}$ in the present experiment might have resulted maximum bunch weight.

With regard to yield the pooled data revealed that maximum yield (74.48 t/ha) in 2 month secondary hardened plant $\left(\mathrm{T}_{2}\right)$ which was closely followed by 3 month secondary hardened plant $(72.55 \mathrm{t} / \mathrm{ha})$ while the minimum yield (59.72 t/ha) was recorded in 5 month secondary hardened plant (Table 5). Similarly the work of Sheela and Nair (2001) and Jhambhale and Patil (2001) are in tune with these findings. The yield increased in 2 month secondary hardened plant over in one month secondary hardened plant persisted up to $\mathrm{T}_{3}$ and thereafter the yield reduced progressively 3 month secondary hardened $\left(\mathrm{T}_{3}\right)$ plant onward to 5 month secondary hardened plant $\left(\mathrm{T}_{5}\right)$. The higher values of yield contributing characters viz. hands/ bunch, finger/hand, finger/bunch and finger weight in 2 month as well as 3 month secondary hardened plantlet had contributed towards more bunch weight and yield in these two treatments. From the present 
investigation, it can be concluded that 2 months secondary hardened plantlets $\left(\mathrm{T}_{2}\right)$ and 3 months secondary hardened plantlets $\left(\mathrm{T}_{3}\right)$ were the best optimum age of tissue culture plantlets for better growth and yield of banana.

\section{References}

Azhakiamanavalan, R. S. and Madhava Rao, V.N. (1980). A comparative study of "Hybrid-135" and "Virupakshi" banana. Proc. Natl. Sem. on Banana. Production Technology, TNAU, Coimbatore, pp. 62-64.

Birhade, R. M., Badgujar, C. D., Desmukh, S. S., Palwe, C. R. and Patil,N. M.(1997). Standardization of banana sucker size and age of tissue culture seedling as planting material. Symposium on optimization of productivity and utilization of banana. 31: 14..

Digrase, S. S., Kulkarni, R. M., Patil, R. F., Vasmate, S. D., Sarsamkar, S. S. and

Pawar, S. S. (2007). Effect of age of tissue culture plantlets on yield and quality of banana (Musa paradisica $\mathrm{L}$.) cv. Grand Nain. Asian J. Hort. 2(1): 6162.

Ingle, P.V. (2000). Propagational studies in banana. Dissertation submitted to MAU,
Parbhani: 84.

Jambhale, N. D. and Patil, S. C. (2001). Extention and training in commercial production of tissue culture plants of banana (1998-2001). Report submitted to department of biotechnology, Govt. of India, New Delhi.

Pillai, O.A.A. and Shanmugavelu, K.G. (1979). Studies on the effect of number of functional leaves on the growth and development of 'Poovan' banana. Total leaf production, phyllochron, total leaf area and leaf function hypothesis. South Indian Horticulture. 24: 83-87.

Sheela,V.L. and Nair, S.R.(2001). Growth, flowering and yield potential of tissue culture banana (Musa AAB cv. Nendran). J.Trop. Agric., 39: 1-4.

Stover, R.H. (1979). Pseudostem growth, leaf production and flower initiation in the 'Grand Nain' banana. Bull. Trop. Agric. Services. 8:37.

Stover, R.H.(1984). Canopy management in 'Valery' and 'Grand Nain' using leaf area index and photosynthetically active radiation measurement. Fruits,39:89-93.

Teaotia, S.S., Bhati, D.R. and Phogat, K.P.S. (1970). Simple partial and multiple correlations of quantitative characters of banana $M$. sapientum var. Harichal. Prog. Hort., 1: 17-24.

\section{How to cite this article:}

Dhanabati, L. and Sarkar, S.K. 2019. Growth and Yield of Banana as Influenced by Age of Secondary Hardened Tissue Culture Plantlets. Int.J.Curr.Microbiol.App.Sci. 8(04): 1128-1135. doi: https://doi.org/10.20546/ijcmas.2019.804.130 